\title{
An Antibiotic Linked to Peptides and Proteins is Released by Electron Capture Dissociation Fourier Transform Ion Cyclotron Resonance Mass Spectrometry
}

\author{
Clifton K. Fagerquist \\ United States Department of Agriculture, Agricultural Research Service, Eastern Regional Research Center, \\ Wyndmoor, Pennsylvania, USA \\ Robert R. Hudgins, Mark R. Emmett,* Kristina Håkansson, \\ and Alan G. Marshall* \\ National High Magnetic Field Laboratory, Florida State University, Tallahassee, Florida, USA
}

Desfuroylceftiofur (DFC) is a bioactive $\beta$-lactam antibiotic metabolite that has a free thiol group. Previous experiments have shown release of DFC from plasma extracts after addition of a disulfide reducing agent, suggesting that DFC may be bound to plasma and tissue proteins through disulfide bonds. We have reacted DFC with $\left[\mathrm{Arg}^{8}\right]$-vasopressin (which has one disulfide bond) and bovine insulin (which has three disulfide bonds) and analyzed the reaction products by use of electron capture dissociation Fourier transform ion cyclotron resonance mass spectrometry (ECD FT-ICR MS), which has previously shown preferential cleavage of disulfide bonds. We observe cleavage of DFC from vasopressin and insulin during ECD, suggesting that DFC is indeed bound to peptides and proteins through disulfide bonds. Specifically, we observed dissociative loss of one, as well as two, DFC species during ECD of $[\text { vasopressin }+2(\mathrm{DFC}-\mathrm{H})+2 \mathrm{H}]^{2+}$ from a single electron capture event. Loss of two DFCs could arise from either consecutive or simultaneous loss, but in any case implies a gas phase disulfide exchange step. ECD of [insulin + DFC $+4 \mathrm{H}]^{4+}$ shows preferential dissociative loss of DFC. Combined with HPLC, ECD FT-ICR-MS may be an efficient screening method for detection of drug-biomolecule binding. (J Am Soc Mass Spectrom 2003, 14, 302-310) (c) 2003 American Society for Mass Spectrometry

\footnotetext{
$\longrightarrow$ eftiofur is a widely used broad-spectrum thirdgeneration cephalosporin antibiotic approved goats, turkeys, and chickens. The four-membered ring structure of $\beta$-lactam antibiotics (which include penicillins and cephalosporins) is responsible for their antimicrobial activity against gram-positive and gram-negative bacteria by covalently binding to, and interrupting the function of, enzymes responsible for bacterial cell wall synthesis. Upon intramuscular injection, ceftiofur is rapidly metabolized $\left(\mathrm{t}_{1 / 2}<10 \mathrm{~min}\right)$ to desfuroylceftiofur (DFC) through hydrolytic cleavage of its thioester bond, generating furoic acid and a sulfhydryl moiety on DFC (Figure 1). Previous experiments have shown

Published online March 10, 2003

Address reprint requests to Dr. C. K. Fagerquist, US Department of Agriculture, Agricultural Research Service, Eastern Regional Research Center, 600 E. Mermaid Lane, Wyndmoor, PA 19038, USA. E-mail: kfagerquist@arserrc.gov

*Also at the Department of Chemistry and Biochemistry, Florida State University, Tallahassee, FL, USA.
}

release of DFC from plasma extracts after addition of a disulfide reducing agent, suggesting that DFC is bound to plasma and tissue proteins at cysteine residues via disulfide bonds $[1,2]$. It is estimated that $89 \%$ of DFC is covalently bound, through disulfide bonds, to plasma and tissue proteins. The remaining $11 \%$ is "free" in the form of the metabolite: Desfuroylceftiofur cysteine disulfide. DFC bound to amino acids, peptides, or proteins through disulfide bonds retains its antibacterial activity because its $\beta$-lactam ring remains intact.

With the advent of electrospray ionization (ESI) [3] and matrix-assisted laser desorption/ionization (MALDI) $[4,5]$ mass spectrometry, it has become relatively easy to desorb and ionize high molecular weight biomolecules into the gas phase. The higher charge states achievable with ESI lower the $\mathrm{m} / \mathrm{z}$ of high molecular weight proteins to within the upper mass range $(\mathrm{m} / \mathrm{z}$ 2000-3000) of quadrupole, ion trap, and Fourier transform ion cyclotron resonance (FT-ICR) mass spectrometers. The number of positive charges (protons) that can attach to a protein depends on the number, location, 
<smiles>CO/N=C(\C(=O)NC1C(=O)N2C(C(=O)O)=C(CSC(=O)c3ccco3)CSC12)c1csc(N)n1</smiles>

\section{Ceftiofur}

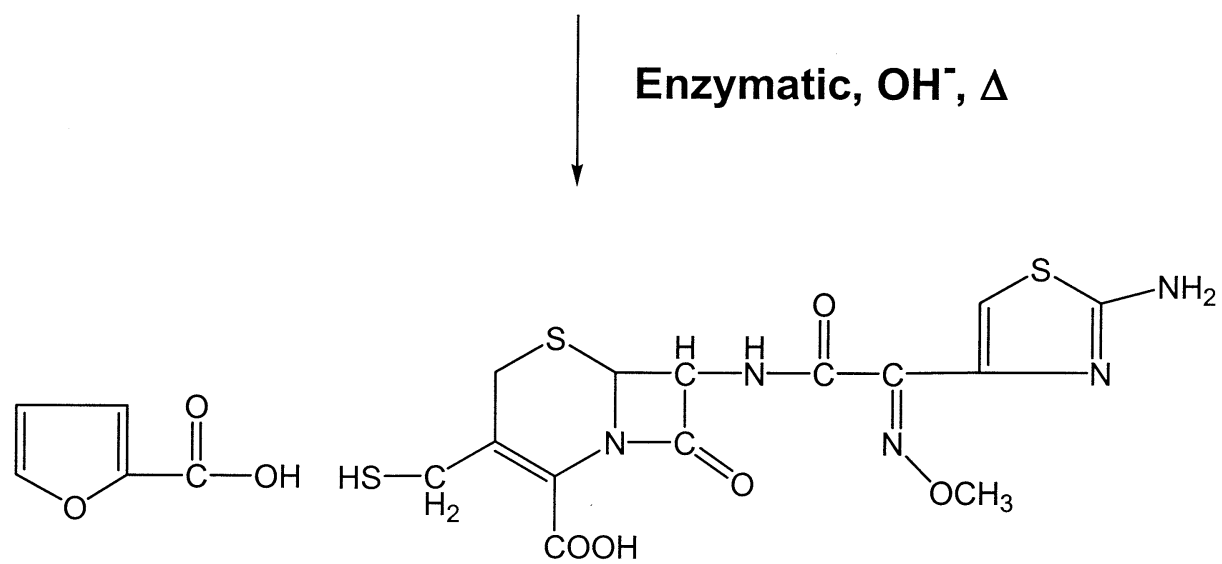

Furoic Acid

\section{Desfuroylceftiofur (DFC)$$
\left(M_{r}=429\right)
$$

Figure 1. Conversion of ceftiofur to desfuroylceftiofur (an antimicrobially active metabolite).

and basicity of the protonation sites in the protein, the $\mathrm{pH}$ of the solution, and ESI source conditions. The side chains of basic residues (arginine, lysine and histidine) are the most favored protonation sites [6].

A number of techniques have been developed to dissociate multiply protonated peptides and proteins to identify primary sequence and post-translational modifications. These techniques include: Collision-activated dissociation (CAD) [7], infrared multiphoton dissociation (IRMPD) [8], surface induced dissociation (SID) [9], blackbody infrared radiative dissociation (BIRD) [10], sustained off-resonance irradiation/collision activated dissociation (SORI-CAD) [11], and electron capture dissociation (ECD) [12-14]. With the exception of ECD, all of the foregoing techniques involve "ergodic" dissociation mechanisms. Ergodic dissociation involves increasing the internal energy of an ion via absorption of infrared radiation or collisions with background neutrals or collision with a surface. The energy deposited into an ion is randomized among all the vibrational degrees-of-freedom. After energy redistribution, dissociation occurs statistically, i.e., random localization of energy into a vibrational mode sufficient to result in bond rupture. The timescale for ergodic dissociation $\left(10^{-9}-10^{-3} \mathrm{~s}\right)$ depends on the ion's internal energy, the number of vibrational modes, and the activation barriers for bond rupture. In contrast, ECD is considered to involve a non-ergodic/non-statistical dissociation mechanism, i.e., fragmentation occurs on a time scale that is much shorter $\left(\sim 10^{-12} \mathrm{~s}\right)$ than the time necessary for energy randomization. ECD utilizes capture of low energy electrons by multiply protonated peptides (or proteins). Electrons generated from a heated filament or dispenser cathode (either internal or external to the bore of the magnet) react with multiply protonated peptide or protein ions in the cell of an FT-ICR mass spectrometer [12-17]. The energy from recombination is at least 4-6 eV. The mechanism of ECD is still a matter of ongoing investigation and debate $[13,14,18,19]$. However, regardless of the mechanism (or mechanisms) involved, ECD produces odd-electron ions ("distonic radical cations") from the even-electron ions generated by the initial ionization process.

ECD has shown unusually strong preference for the dissociation of disulfide bonds in addition to extensive cleavage of backbone amide bonds in peptides and proteins. Consequently, it has rapidly been exploited in "top-down" proteomics research because of the high sequence coverage obtained [20, 21]. In addition, because of the non-ergodic nature of ECD, non-covalent 
interactions are not affected, and thus tertiary and quarternary structures are left intact [22-24]. ECD has also been shown to be useful in identifying the location of co- and post-translational modification. Ergodic dissociation techniques may cause dissociative loss of protein modifications, making it difficult to determine the site of attachment. ECD has the advantage of cleavage of the peptide backbone with retention of the modification, allowing the site of the modification to be identified [25-30].

It is well known that drugs in general, and antibiotics in particular, often have complex and sometimes unexpected interactions with biomolecules beyond their intended target. To analyze drug/target and drug/nontarget interactions, it is important to examine the nature of the drug/biomolecule binding, i.e., covalent versus non-covalent, reversible versus non-reversible binding. Very recently, Haselmann et al. reported the analysis of a non-covalently bound complex of a modified glycopeptide antibiotic with its target peptide using ECD FT-ICR MS [31]. Here, we seek to exploit ECD's preference for cleavage of disulfide bonds as a method to detect DFC attachment to peptides and proteins through disulfide bonds. We also discuss the feasibility of combining ECD FT-ICR MS with high performance liquid chromatography (HPLC) as a screening technique for the detection of DFC attachment to plasma and tissue proteins. To the best of our knowledge, the present results constitute the first reported use of ECD FT-ICR MS to analyze the binding of a covalently bound drug/biomolecule complex. Portions of this work were previously presented in abstract form [32].

\section{Materials and Methods}

Bovine insulin and $\left[\mathrm{Arg}^{8}\right]$-vasopressin (C-terminal amide) were purchased from ICN Pharmaceuticals (Costa Mesa, CA). Ceftiofur was graciously provided by Rex Hornish (Pharmacia Animal Health, Kalamazoo, MI). The reaction of ceftiofur and vasopressin was as follows: Ceftiofur was first dissolved in methanol after which an equal amount of water was added to generate a $2 \times 10^{-4} \mathrm{M}$ ceftiofur solution. $0.25 \mathrm{~mL}$ of a $\sim 0.02 \mathrm{M}$ solution of sodium hydroxide $(\mathrm{pH} \sim 11-12)$ was then added to $1.0 \mathrm{~mL}$ of the ceftiofur solution to generate desfuruoylceftiofur (DFC) as shown in Figure 1 [33]. The mixture was allowed to react at $36-40{ }^{\circ} \mathrm{C}$ for $10-30$ min in a heated sonicator or temperature controlled water bath. The solution was then acidified with $0.3 \mathrm{~mL}$ of $0.1 \%$ formic acid to reduce the $\mathrm{pH}$ before reacting the ceftiofur solution with the peptide. $0.2 \mathrm{mg}$ of $\mathrm{Arg}^{8}$ vasopressin was added to the solution and reacted for $1 \mathrm{~h}$ at $40{ }^{\circ} \mathrm{C}$ in a temperature controlled water bath. The final solution was then diluted 100-fold in water to provide a working concentration and to further dilute the salts in the sample.

The reaction of ceftiofur and bovine insulin was as follows. The starting solutions were: $0.17 \mathrm{M}$ solution of ammonium hydroxide $(\mathrm{pH}=10.5) ; 0.1 \%$ formic acid solution ( $\mathrm{pH}=3.2) ; 2.0 \times 10^{-4} \mathrm{M}$ solution of ceftiofur in 1:1 (MeOH: $\left.\mathrm{H}_{2} \mathrm{O}\right) ; 1.0 \times 10^{-4} \mathrm{M}$ solution of insulin in water. $1.0 \mathrm{~mL}$ of ceftiofur solution was reacted with 0.5 $\mathrm{mL}$ of $\mathrm{NH}_{4} \mathrm{OH}$ for $30 \mathrm{~min}$ at $40{ }^{\circ} \mathrm{C}$ in a temperaturemonitored sonicator. $0.5 \mathrm{~mL}$ of $0.1 \%$ formic acid was then added, lowering the $\mathrm{pH}$ to $\sim 7.1 .0 \mathrm{ml}$ of the insulin solution was then added to this solution and allowed to react at $40{ }^{\circ} \mathrm{C}$ for $55 \mathrm{~min}$. Finally, the solution was further acidified with formic acid until the $\mathrm{pH}$ was 3.2, and then, $1.0 \mathrm{ml}$ of $\mathrm{MeOH}$ was added to facilitate electrospray.

Samples were analyzed with a homebuilt, passively shielded, 9.4 tesla FT-ICR mass spectrometer [34]. Samples were introduced into the mass spectrometer by a direct infusion microelectrospray source [35] using a syringe pump (Harvard Apparatus, Inc., Holliston, MA) operated at $400 \mathrm{~nL} / \mathrm{min} .2 \mathrm{kV}$ was applied between the microspray emitter and the heated capillary entrance. The magnitude of the parent ions of interest were increased by mass-selective external ion accumulation employing a quadrupole mass filter [36]. A finer isolation was achieved by stored waveform inverse Fourier transform (SWIFT) mass-selective ion ejection [37]. The isolated ions were then irradiated with low energy electrons for $50 \mathrm{~ms}$. An indirectly-heated electron dispenser cathode (10 mm diameter, no. 1109, Heatwave, Watsonville, CA) was used for electron irradiation [15-17].

\section{Results and Discussion}

ECD of [Vasopressin $+2(D F C-H)+2 H]^{2+}$

Figure 2 shows the mass spectrum following ECD of [vasopressin $+2(\mathrm{DFC}-\mathrm{H})+2 \mathrm{H}]^{2+}$. A weak signal is observed for [vasopressin $+2(\mathrm{DFC}-\mathrm{H})+\mathrm{H}]^{+}$, corresponding to $\mathrm{H} \cdot$ atom ejection from the charge-reduced species [vasopressin $+2(\mathrm{DFC}-\mathrm{H})+2 \mathrm{H}]^{+}$. (Note that the native structure of vasopressin is cyclic, and a hydrogen is lost from each DFC on forming a DFC/ vasopressin disulfide bond. The charge of the ion results from addition of one or two protons. For example, the mass of [vasopressin $+2(\mathrm{DFC}-\mathrm{H})+2 \mathrm{H}]^{2+}$ is the mass of vasopressin plus the mass of two DFC molecules minus the mass of two hydrogen atoms plus the mass of two protons.) The signal from [vasopressin + $2(\mathrm{DFC}-\mathrm{H})+2 \mathrm{H}]^{+}{ }^{\cdot}$ is also weak. The low abundances of these species may reflect their instability given the amount of internal energy deposited into the molecule during the recombination process. The most abundant fragment ions in Figure 2 correspond to $\beta$-lactam ring cleavage $(m / z 1700)$ and dissociative loss of one DFC, but without its thiyl sulfur $(m / z$ 1544). These fragmentations are schematically shown in Figure 3 and could originate from dissociative losses from either [vasopres$\sin +2(\mathrm{DFC}-\mathrm{H})+2 \mathrm{H}]^{+}$or $[$vasopressin $+2(\mathrm{DFC}-\mathrm{H})+$ $\mathrm{H}^{+}$. Based on accurate mass measurement, we have tentatively identified the peak at $\mathrm{m} / \mathrm{z} 1910$ as dissociative loss of a methoxy group from [vasopressin + 


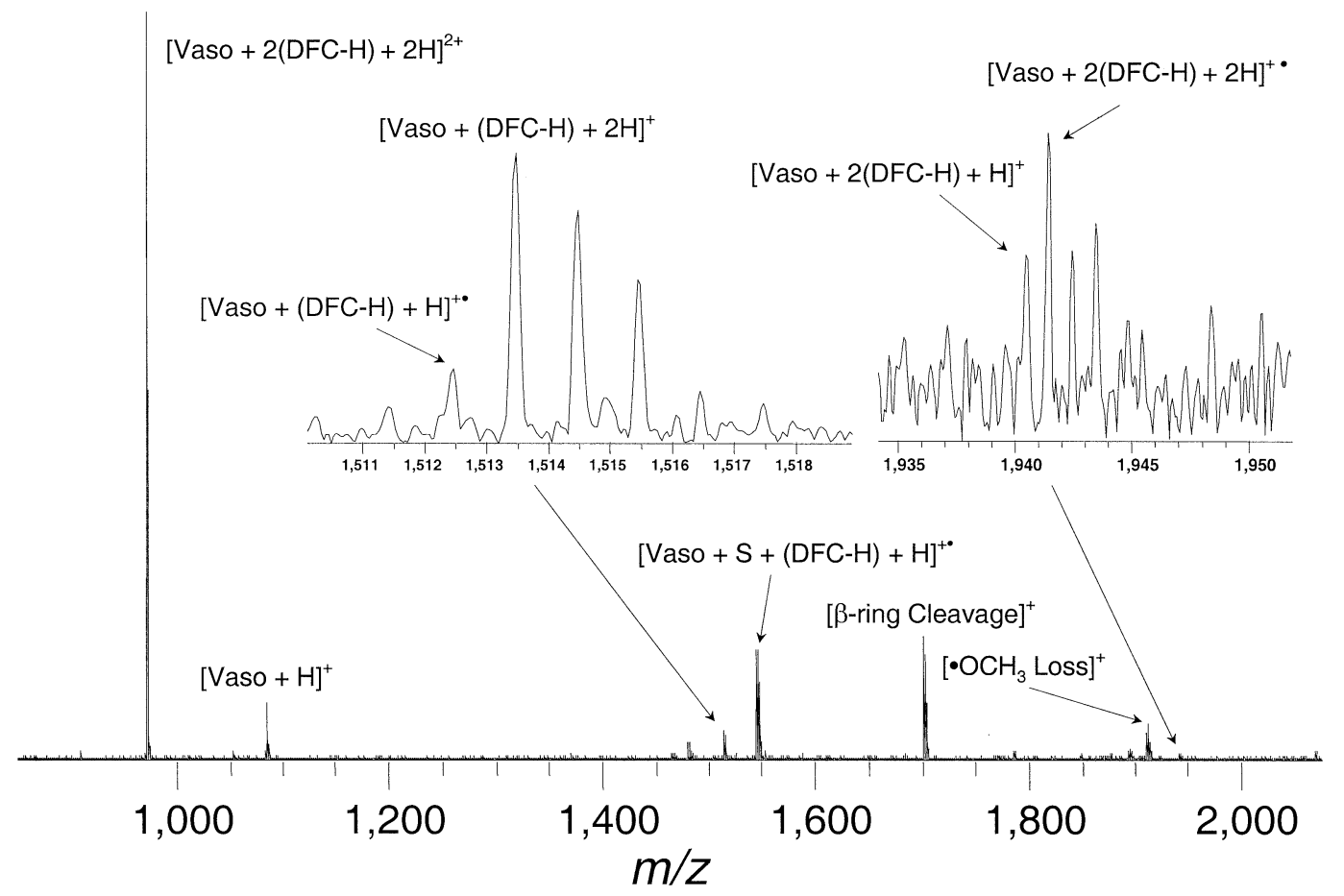

Figure 2. FT-ICR mass spectrum following ECD of $\left[\mathrm{Arg}^{8} \text {-vasopressin }+2(\mathrm{DFC}-\mathrm{H})+2 \mathrm{H}\right]^{2+}$.

$2(\mathrm{DFC}-\mathrm{H})+2 \mathrm{H}]^{+\cdot}$, presumably from the imino-methoxy group of DFC. That fragmentation is also schematically shown in Figure 3. Figure 2 also shows a peak at $\mathrm{m} / \mathrm{z} 1513$ (insert) which is the result of either loss of 428 (i.e., DFC-H) from [vasopressin + 2(DFC-H) + $2 \mathrm{H}^{+\cdot}$ or loss of 427 (i.e., DFC-2H) from [vasopressin + $2(\mathrm{DFC}-\mathrm{H})+\mathrm{H}]^{+}$. A weak peak at $m / z 1512$ (insert) is the result of either loss of 429 (i.e., DFC) from [vasopressin $+2(\mathrm{DFC}-\mathrm{H})+2 \mathrm{H}]^{+\cdot}$ or loss of 428 from [vasopressin + $2(\mathrm{DFC}-\mathrm{H})+\mathrm{H}]^{+}$. Finally, a peak at $m / z 1084$ is the result of either loss of 857 [i.e., DFC + (DFC-H)] from [vasopressin $+2(\mathrm{DFC}-\mathrm{H})+2 \mathrm{H}]^{+\cdot}$ or loss of 856 [i.e., $2(\mathrm{DFC}-\mathrm{H})]$ from [vasopressin $+2(\mathrm{DFC}-\mathrm{H})+\mathrm{H}]^{+}$. Either corresponds to loss of two DFC species from a single electron capture event. The peak at $m / z 1084$ is presumably the regenerated native cyclic peptide structure of vasopressin (see below).

\section{Sites of Protonation of [Vasopressin $+2(D F C-H)$ $+2 \mathrm{H}]^{2+}$}

To our knowledge, there are no measurements of the gas-phase proton affinity or gas-phase basicity of ceftiofur or DFC. However, the most likely protonation site for DFC is the 2-aminothiazole functional group, whose proton affinity (PA) is $222.4 \mathrm{kcal} / \mathrm{mol}$ [38]. In Figure 4, we have identified the most likely protonation sites in the [vasopressin + 2(DFC-H)] complex along with their gas phase PA's. We find that the PA of DFC is 7.7 $\mathrm{kcal} / \mathrm{mol}$ greater than the PA of the N-terminal amine. The most likely protonation sites of [vasopressin +
$2(\mathrm{DFC}-\mathrm{H})+2 \mathrm{H}]^{2+}$ are therefore the side-chain of the $\mathrm{Arg}^{8}$, and either the DFC attached to $\mathrm{Cys}^{1}$ or the peptide $\mathrm{N}$-terminus. Such configurations would place protons on the most basic sites in the complex while at the same time minimizing the Coulomb repulsion between the two charges.

As mentioned previously, the most abundant fragment ions in Figure 2 are $\beta$-lactam ring cleavage (resulting in a fragment ion at $m / z 1700$ ), and dissociative loss of a DFC minus a sulfur atom, (resulting in a fragment ion at $m / z$ 1544). Both fragmentation channels are also dominant channels in the collision-induced dissociation (CID) of $[\mathrm{M}+\mathrm{H}]^{+}$of desfuroylceftiofur cysteine disulfide (DCCD), a biomarker of ceftiofur [39]. The loss of a methoxy group from [vasopressin + $2(\mathrm{DFC}-\mathrm{H})+2 \mathrm{H}]^{+\cdot}$ is interesting because this dissociative loss is not observed in the CID of DCCD [39].

\section{ECD of [Insulin + DFC $+4 H]^{4+}$}

Figure 5 shows the mass spectrum following ECD of $[\text { insulin }+\mathrm{DFC}+4 \mathrm{H}]^{4+}$. (Note that the mass of [insulin $+\mathrm{DFC}+4 \mathrm{H}]^{4+}$ is the mass of insulin plus the mass of one DFC molecule plus the mass of four protons). We find far fewer fragmentation channels than were observed from ECD of [vasopressin $+2(\mathrm{DFC}-\mathrm{H})+2 \mathrm{H}]^{2+}$. The isotopic distribution centered at $m / z 2056$ corresponds to the charge-reduced [insulin $+\mathrm{DFC}+4 \mathrm{H}]^{3+\cdot}$. $\mathrm{H} \cdot$ atom ejection from [insulin $+\mathrm{DFC}+4 \mathrm{H}]^{3+\cdot}$ is not observed. The isotopic distribution centered at $m / z 1912$ corresponds to [insulin $+3 \mathrm{H}]^{3+}$ and thus dissociative 


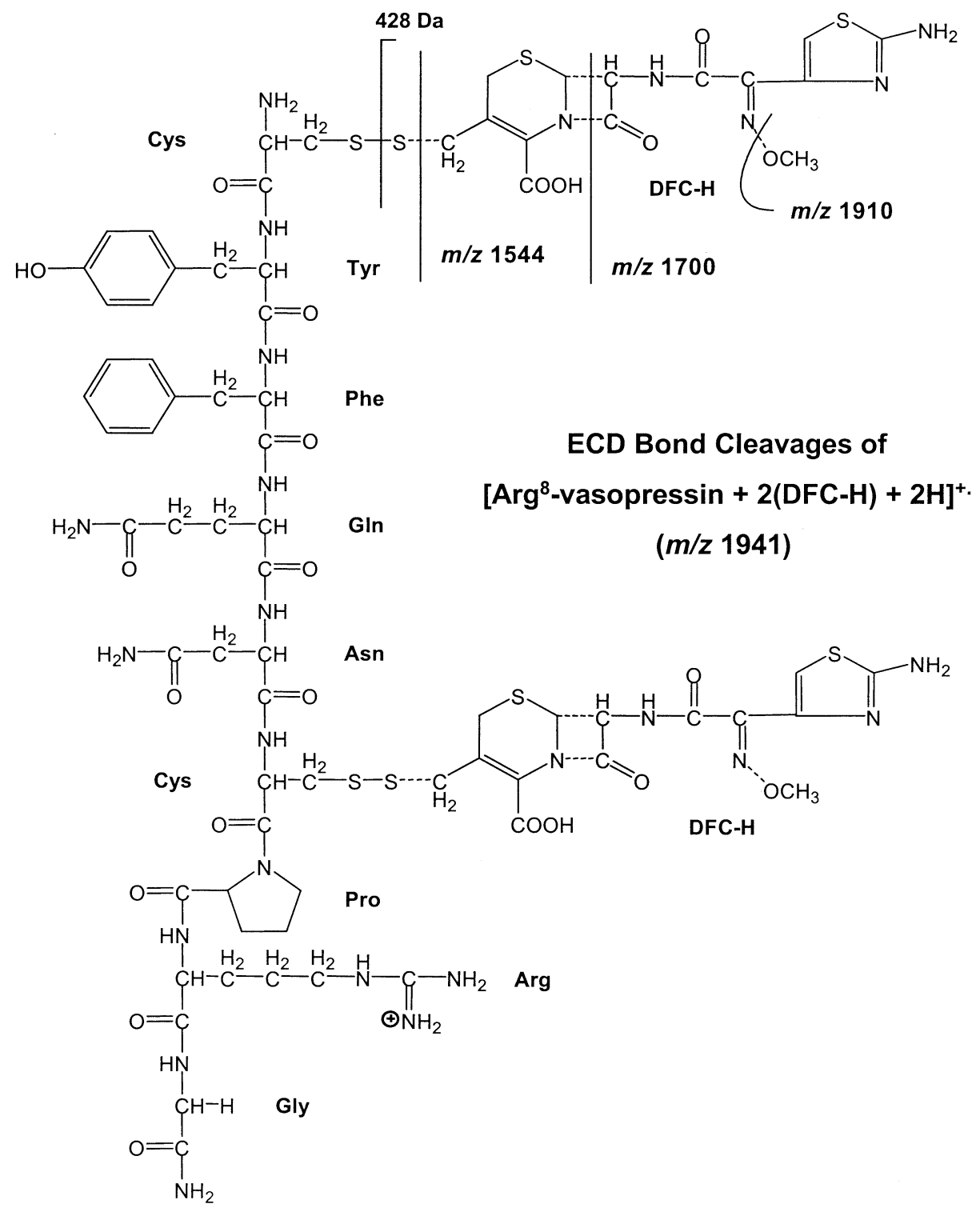

Figure 3. Possible sites of cleavage for ECD of $\left[\mathrm{Arg}^{8} \text {-vasopressin }+2(\mathrm{DFC}-\mathrm{H})(\mathrm{DFC}-\mathrm{H})+2 \mathrm{H}\right]^{+}$.

loss of 430 (i.e., a DFC and an H. atom). No doubly charged ions are observed.

\section{Sites of Protonation of [Insulin + DFC $+4 \mathrm{H}]^{4+}$}

Bovine insulin is a two-chain (A and B) protein with four basic residues: Two histidines, one lysine, and one arginine, all located on the B-chain. Two disulfide bonds connect the A and B chains. The A-chain has one intrachain disulfide bond. Figure 6 shows one possible configuration for [insulin + DFC] (the gas phase PA's of the 2-aminothiazole group of DFC and the four basic residues are also shown), however, one cannot determine with complete certainty the protonation sites (or even the site of DFC attachment for [insulin + DFC + $\left.4 \mathrm{H}]^{4+}\right)$. Although the 2-aminothiazole group of DFC has a PA that is less than that of the side-chains of basic residues, it is possible that DFC could be protonated if it reduced the Coulomb repulsion that might occur if all four protons were located on the B-chain.

\section{Bond Cleavage by ECD}

It is interesting to note that there is no significant peptide backbone cleavage observed in the ECD spectra of [vasopressin $+2($ DFC-H $)+2 \mathrm{H}]^{2+}$ and [insulin $+\mathrm{DFC}+4 \mathrm{H}]^{4+}$. The process which results in efficient cleavage of disulfide bonds in these complexes appears to also result in a concomitant lack of peptide backbone cleavages (although we do observe fragmentation of the antibiotic adducts for ECD of [vasopressin $\left.+2(\mathrm{DFC}-\mathrm{H})+2 \mathrm{H}]^{2+}\right)$. One can only conclude that the antibiotic/peptide (and antibiotic/ 


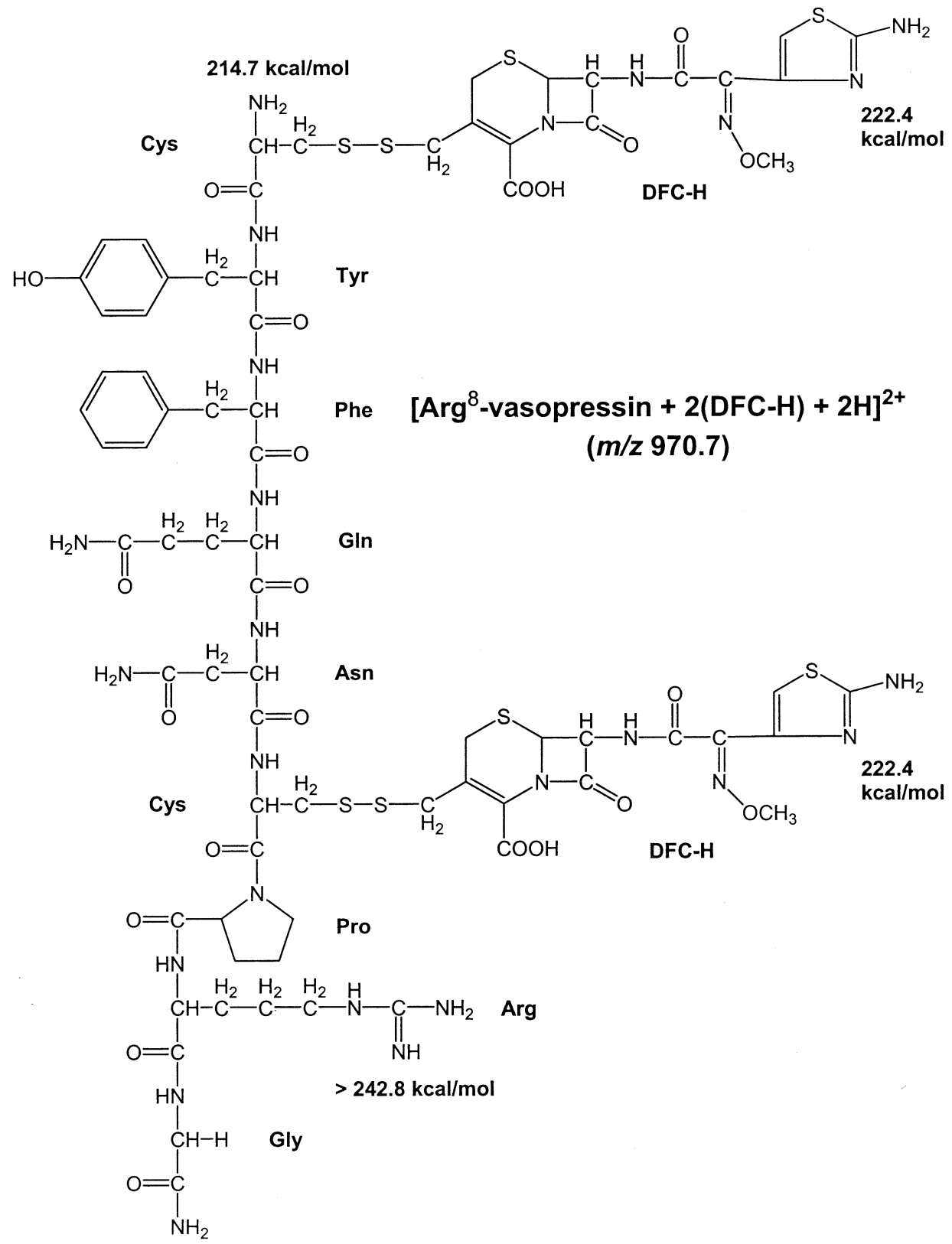

Figure 4. Chemical structure of $\left[\mathrm{Arg}^{8}\right]$-vasopressin with two DFC molecules attached via disulfide bonds. Possible protonation sites are identified by their gas phase proton affinities.

protein) disulfide bond would appear to have a significantly higher efficiency for cleavage than that of the peptide backbone. Longer electron irradiation times did not significantly alter our results. Previous researchers have similarly noted a reduction of peptide backbone cleavage in ECD spectra of peptides and proteins that have intramolecular disulfide bonds [13].

It is possible that use of "hot" ECD may lead to more extensive cleavage of these antibiotic/peptide (protein) complexes, including the peptide backbone, and thus might give more specific information about the positions of antibiotic attachment (assuming antibiotic attachment is not completely lost). However, in the present study, we deliberately exploit the preference of ECD to cleave disulfide bonds to confirm the nature of antibiotic/peptide (protein) binding and thus, the sites of attachment, i.e., cysteine residues. Given the facile loss of DFC from ECD of $\mathrm{DFC} /$ vasopressin and DFC/insulin complexes, future experiments might involve ECD of antibiotic/ protein complexes for larger proteins, e.g., lysozyme or bovine serum albumin. Such experiments would have both a practical utility (a screening method for DFC attached to larger proteins) as well as theoretical value (what is the largest protein for which one observes ECD dissociative loss of a covalently bound drug adduct). 


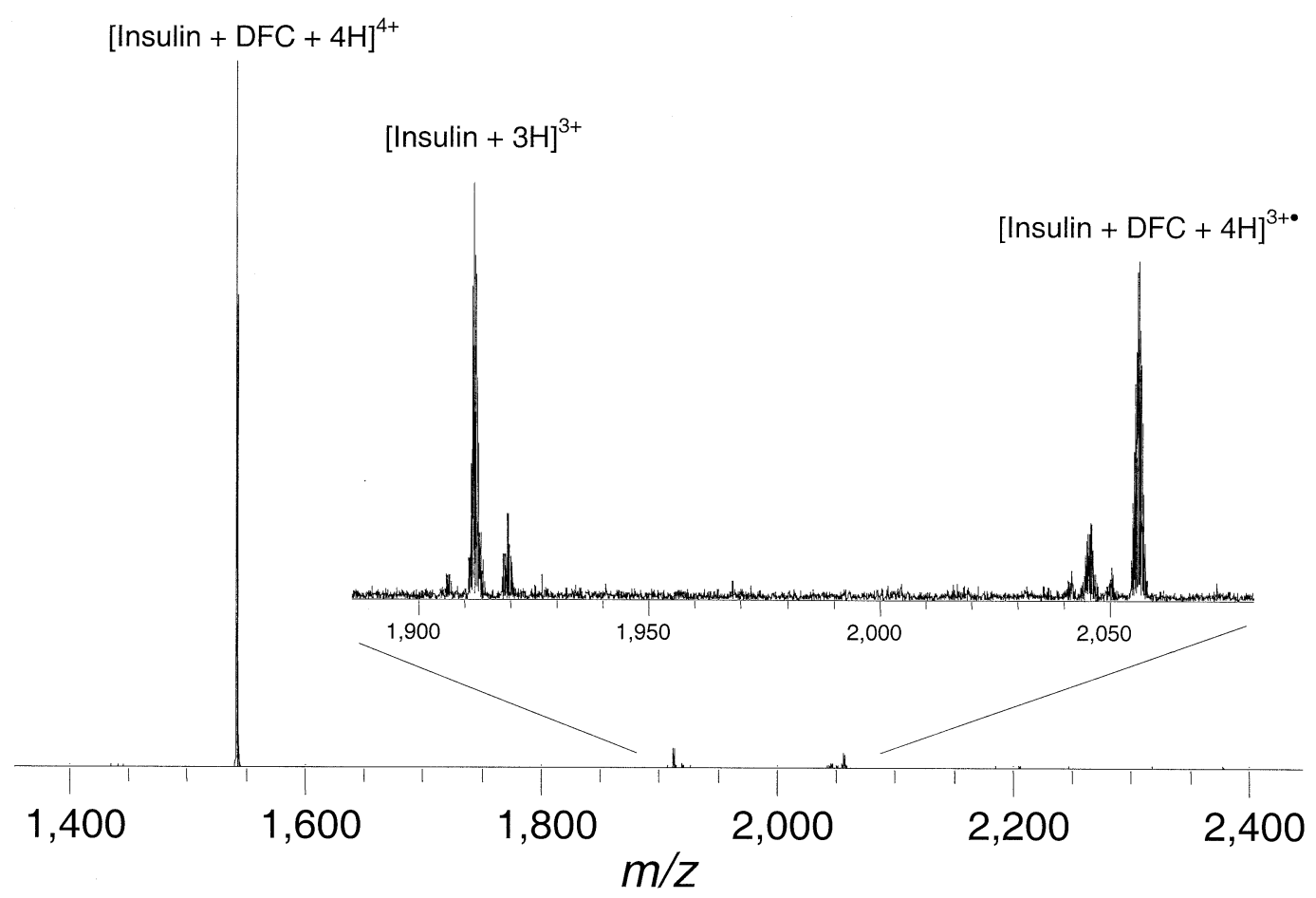

Figure 5. FT-ICR mass spectrum following ECD of [insulin + DFC $+4 \mathrm{H}]^{4+}$.

\section{Conclusions}

The facile loss of DFC from [vasopressin +2 (DFC-H) $+2 \mathrm{H}]^{2+}$ and [insulin $\left.+\mathrm{DFC}+4 \mathrm{H}\right]^{4+}$ when subjected to ECD suggests that DFC is indeed bound to proteins through disulfide bonds. In addition, ECD of $[\text { vasopressin }+2(\mathrm{DFC}-\mathrm{H})+2 \mathrm{H}]^{2+}$ may also occur by $\mathrm{H} \cdot$ atom ejection followed by ergodic dissociations, which may include a rearrangement/fragmentation that transfers a hydrogen atom from a DFC to the peptide [39]. However, ECD of [insulin + (DFC) + $4 \mathrm{H}]^{4+}$ does not seem to occur by that mechanism because $\mathrm{H} \cdot$ atom ejection is not observed. Gas-phase disulfide exchange appears to play a partial role in the loss of two DFCs during ECD of [vasopressin + $2(\mathrm{DFC}-\mathrm{H})+2 \mathrm{H}]^{2+}$, and in loss of one DFC and a hydrogen atom (loss of 430) from ECD of [insulin + $\mathrm{DFC}+4 \mathrm{H}]^{4+}$.

It has been documented that the binding of DFC to plasma and tissue proteins extends the half-life of the antibiotic [40]. In consequence, much of the residual ceftiofur is in the form of protein-bound DFC and thus constitutes an antibiotic residue. The facile loss of DFC from vasopressin/DFC and insulin/DFC suggests that, if coupled with HPLC, ECD FT-ICR MS may prove to be a valuable technique for the detection of DFC attached to proteins. In contrast to current methods, which require chemical modifications/derivatizations prior to analysis [1, 2], the present technique is sensitive, accurate, and requires less chemical manipulations that can lead to additional sample loss.

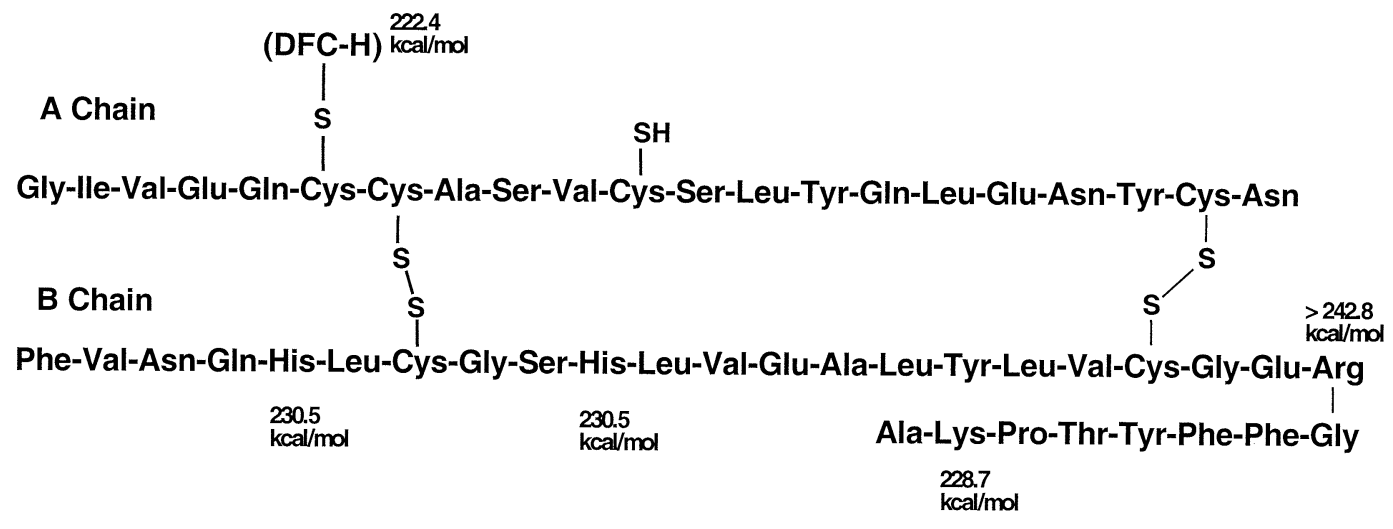

Figure 6. Primary sequence of bovine insulin with one DFC attached via a disulfide bond. Possible protonation sites are identified by their gas phase proton affinities. 


\section{Acknowledgments}

The authors thank Rex Hornish (Pharmacia Animal Health, Kalamazoo, Michigan) for generously providing samples of ceftiofur. They also thank Chris L. Hendrickson and John P. Quinn for technical advice and assistance. This work was supported by the U.S. Department of Agriculture (CRIS 1935-42000-044-00D), NSF National High-Field FT-ICR Mass Spectrometry Facility (CHE-9909502), Florida State University, and the National High Magnetic Field Laboratory in Tallahassee, Florida.

Mention of a brand or firm name does not constitute an endorsement by the U.S. Department of Agriculture over others of a similar nature not mentioned.

\section{References}

1. Beconi-Barker, M. G.; Roof, R. D.; Millerioux, L.; Kausche, F. M.; Vidmar, T. J.; Smith, E. B.; Callahan, J. K.; Hubbard, V. L.; Smith, G. A.; Gilbertson, T. J. Determination of Ceftiofur and Its Desfuroylceftiofur-Related Metabolites in Swine Tissues by High-Performance Liquid Chromatography. J. Chromatogr. B 1995, 673, 231-244.

2. Jaglan, P. S.; Cox, B. L.; Arnold, T. S.; Kubrick, M. F.; Stuart, D. J.; Gilbertson, T. J. Liquid Chromatographic Determination of Desfuroylceftiofur Metabolite of Ceftiofur as Residue in Cattle Plasma. J. Assoc. Off. Anal. Chem. 1990, 73, 26-30.

3. Fenn, J. B.; Mann, M.; Meng, C. K.; Wong, S. F.; Whitehouse, C. M. Electrospray Ionization-Principles and Practice. Mass Spectrom. Rev. 1990, 9, 37-70.

4. Tanaka, K.; Waki, H.; Ido, Y.; Akita, S.; Yoshida, Y.; Yoshida, T. Protein and Polymer Analyses up to $m / z$ 100,000 by Laser Ionization Time-of-Flight Mass Spectrometry. Rapid Commun. Mass Spectrom. 1988, 2, 151-153.

5. Karas, M.; Hillenkamp, F. Laser Desorption Ionization of Proteins with Molecular Masses Exceeding 10,000 Daltons. Anal. Chem. 1988, 60, 2299-2301.

6. Dongre, A. R.; Jones, J. L.; Somogyi, A.; Wysocki, V. H. Influence of Peptide Composition, Gas-Phase Basicity, and Chemical Modification on Fragmentation Efficiency: Evidence for the Mobile Proton Model. J. Am. Chem. Soc. 1996, 118, 8365-8374.

7. Loo, J. A.; Udseth, H. R.; Smith, R. D. Collision Effects on the Charge Distribution of Ions from Large Molecules, Formed by Electrospray Ionization-Mass Spectrometry. Rapid Commun. Mass Spectrom. 1988, 2, 207-210.

8. Little, D. P.; Speir, J. P.; Senko, M. W.; O'Connor, P. B.; McLafferty, F. W. Infrared Multiphoton Dissociation of Large Multiply Charged Ions for Biomolecule Sequencing. Anal. Chem. 1994, 66, 2809-2815.

9. Ijames, C. F.; Wilkins, C. L. Surface-Induced Dissociation by Fourier Transform Mass Spectrometry. Anal. Chem. 1990, 627, 1295-1299.

10. Price, W. D.; Schnier, P. D.; Williams, E. R. Tandem Mass Spectrometry of Large Biomolecule Ions by Blackbody Infrared Radiative Dissociation. Anal. Chem. 1996, 68, 859-866.

11. Gauthier, J. W.; Trautman, T. R.; Jacobson, D. B. Sustained Off-Resonance Irradiation for Collision-Activated Dissociation Involving Fourier Transform Mass Spectrometry Collision-Activated Dissociation Technique that Emulates Infrared Multiphoton Dissociation. Anal. Chim. Acta 1991, 246, 211-225.

12. Zubarev, R. A.; Kelleher, N. L.; McLafferty, F. W. Electron Capture Dissociation of Multiply Charged Protein Cations. A Nonergodic Process. J. Am. Chem. Soc. 1998, 120, 32653266.

13. Zubarev, R. A.; Kruger, N. A.; Fridriksson, E. K.; Lewis, M. A.; Horn, D. M.; Carpenter, B. K.; McLafferty, F. W.
Electron Capture Dissociation of Gaseous MultiplyCharged Proteins is Favored at Disulfide Bonds and Other Sites of High Hydrogen Atom Affinity. J. Am. Chem. Soc. 1999, 121, 2857-2862.

14. Zubarev, R. A.; Horn, D. M.; Fridriksson, E. K.; Kelleher, N. L.; Kruger, N. A.; Lewis, M. A.; Carpenter, B. K. McLafferty F. W. Electron Capture Dissociation for Structural Characterization of Multiply Charged Protein Cations. Anal. Chem. 2000, 72, 563-573.

15. Quinn, J. P.; Håkansson, K.; McFarland, M. A.; Hendrickson, C. L.; Marshall, A. G. Rapid Electron Capture Dissociation with Simultaneous Laser Access for Fourier Transform Ion Cyclotron Resonance Mass Spectrometry. Proc. 50th ASMS Conf. Mass Spectrom. Allied Topics; Orlando, FL, June 2-6, 2002.

16. Tsybin, Y. O.; Håkansson, P.; Budnik, B. A.; Haselmann, K. F.; Kjeldsen, F.; Gorshkov, M.; Zubarev, R. A. Improved LowEnergy Electron Injection Systems for High Rate Electron Capture Dissociation in Fourier Transform Ion Cyclotron Resonance Mass Spectrometry. Rapid Commun. Mass Spectrom. 2001, 15, 1849-1854.

17. Haselmann, K. F.; Budnik, B. A.; Olsen, J. V.; Nielsen, M. L.; Reis, C. A.; Clausen, H.; Johnsen, A. H.; Zubarev, R. A. Advantages of External Accumulation for Electron Capture Dissociation in Fourier Transform Mass Spectrometry. Anal. Chem. 2001, 73, 2998-3005.

18. Hudgins, R. R.; Håkansson, K.; Marshall, A. G. ECD on Disulfide-Linked Helical Peptides: Measuring the Efficiency of ECD at Sites Remote from Electron Capture. Proc. 49th ASMS Conf. Mass Spectrom. Allied Topics; Chicago, IL May 27-31, 2001.

19. Hudgins, R. R.; Håkansson, K.; Quinn, J. P.; Hendrickson, C. L.; Marshall, A. G. Electron Capture Dissociation of Peptides and Proteins Does Not Require a Hydrogen Atom Mechanism. Proc. ASMS Conf. Mass Spectrom. Allied Topics; Orlando, FL, June 2-6, 2002.

20. Ge, Y.; Lawhorn, B. G. El; Naggar, M.; Strauss, E.; Park, J.-H.; Begley, T. P.; McLafferty, F. W. Top Down Characterization of Larger Proteins (45 kDa) by Electron Capture Dissociation Mass Spectrometry. J. Am. Chem. Soc. 2002, 124, 672-678.

21. Sze, S. K.; Ge, Y.; Oh, H.; McLafferty, F. W. Top-Down Mass Spectrometry of a $29 \mathrm{kDa}$ Protein for Characterization of Any Posttranslational Modification to Within One Residue. Proc. Natl. Acad. Sci. U.S.A. 2002, 99, 1774-1779.

22. Horn, D. M.; Ge, Y.; McLafferty, F. W. Activated Ion Electron Capture Dissociation for Mass Spectral Sequencing of Larger (42 kDa) Proteins. Anal. Chem. 2000, 72, 4778-4784.

23. Horn, D. M.; Breuker, K.; Frank, A. J.; McLafferty, F. W. Kinetic Intermediates in the Folding of Gaseous Protein Ions Characterized by Electron Capture Dissociation Mass Spectrometry. J. Am. Chem. Soc. 2001, 123, 9792-9799.

24. Breuker, K.; Oh, H.; Horn, D. M.; Cerda, B. A.; McLafferty, F. W. Detailed Unfolding and Folding of Gaseous Ubiquitin Ions Characterized by Electron Capture Dissociation. J. Am. Chem. Soc. 2002, 124, 6407-6420.

25. Kelleher, N. L.; Zubarev, R. A.; Bush, K.; Furie, B.; Furie, B. C.; McLafferty, F. W.; Walsh, C. T. Localization of Labile Posttranslational Modifications by Electron Capture Dissociation: The Case of Gamma-Carboxyglutamic Acid. Anal. Chem. 1999, $71,4250-4253$.

26. Mirgorodskaya, E.; Roepstorff, P.; Zubarev, R. A. Localization of O-Glycosylation Sites in Peptides by Electron Capture Dissociation in a Fourier Transform Mass Spectrometer. Anal. Chem. 1999, 71, 4431-4436.

27. Stensballe, A.; Jensen, O. N.; Olsen, J. V.; Haselmann, K. F.; Zubarev, R. A. Electron Capture Dissociation of Singly and 
Multiply Phosphorylated Peptides. Rapid Comm. Mass Spectrom. 2000, 14, 1793-1800.

28. Håkansson, K.; Cooper, H. J.; Emmett, M. R.; Costello, C. E.; Marshall, A. G.; Nilsson, C. L. Electron Capture Dissociation and Infrared Multiphoton Dissociation MS/MS of an NGlycosylated Tryptic Peptide to Yield Complementary Sequence Information. Anal. Chem. 2001, 73, 4530-4536.

29. Guan, Z.; Griffin, P. R. Localization and Characterization of Peptide Acylation with Ester Linkage by Electron Capture Dissociation FTICR/MS. Proc. ASMS Conf. Mass Spectrom. Allied Topics; Orlando, FL, June 2-6, 2002.

30. Shi, S. D.-H.; Hemling, M. E.; Carr, S. A.; Horn, D. M.; Lindh, I.; McLafferty, F. W. Phosphopeptide/Phosphoprotein Mapping by Electron Capture Dissociation Mass Spectrometry. Anal. Chem. 2001, 73, 19-22.

31. Haselmann, K. F.; Jorgensen, T. J.; Budnick, B. A.; Jensen, F.; Zubarev, R. A. Electron Capture Dissociation of Weakly Bound Polypeptide Polycationic Complexes. Rapid Commun. Mass Spectrom. 2002, 16, 2260-2265.

32. Fagerquist, C. K.; Hudgins, R. R.; Emmett, M. R.; Håkansson, K.; Marshall, A. G. Selective Cleavage of an Antibiotic Drug Molecule from Peptides and Proteins in the Gas Phase by Electron Capture Dissociation Fourier Transform Ion Cyclotron Resonance Mass Spectrometry. Proc. 50th ASMS Conf. Mass Spectrom. Allied Topics; Orlando, FL June 2-6, 2002.
33. Sunkara, G.; Navarre, C. B.; Kompella, U. B. Influence of pH and Temperature on Kinetics of Ceftiofur Degradation in Aqueous Solutions. J. Pharm. Pharmacol. 1999, 51, 249-255.

34. Senko, M. W.; Hendrickson, C. L.; Pasa-Tolic, L.; Marto, J. A.; White, F. M.; Guan, S. Marshall A. G. Electrospray Ionization Fourier Transform Ion Cyclotron Resonance at 9.4 T. Rapid Commun. Mass Spectrom. 1996, 10, 1824-1828.

35. Emmett, M. R.; Caprioli, R. M. Micro-Electrospray Mass Spectrometry Ultra-High Sensitivity Analysis of Peptides and Proteins. J. Am. Soc. Mass. Spectrom. 1994, 5, 605-613.

36. Hendrickson, C. L.; Quinn, J. P.; Emmett, M. R.; Marshall, A. G. Mass-Selective External Ion Accumulation for Fourier Transform Ion Cyclotron Resonance Mass Spectrometry. Proc. 49th ASMS Conf. Mass Spectrom. Allied Topics; Chicago, IL May 27-31, 2001.

37. Marshall, A. G.; Wang, T. C. L.; Ricca, T. L. Tailored Excitation for Fourier Transform Ion Cyclotron Resonance Mass Spectrometry. J. Am. Chem. Soc. 1985, 107, 7893-7897.

38. Hunter, E. P.; Lias, S. G. Evaluated Gas Phase Basicities and Proton Affinities of Molecules: An Update. J. Phys. Chem. Ref. Data 1998, 27, 3, 413-656.

39. Fagerquist C. K.; Fiddler M., unpublished.

40. Hornish, R. E.; Kotarski, S. F. Cephalosporins in Veterinary Medicine-Ceftiofur Use in Food Animals. Curr. Topics Med. Chem. 2002, 2, 717-731. 